egyetemi adjunktus

ME ÁJK

\title{
Gondolatok Antal Tamás „Az Igazságügyi Minisztérium története (1867-1944). Fejezetek a polgári kor évtizedéből” című kötetéről ${ }^{1}$
}

Antal Tamás jelentôs terjedelmú munkája hiánypótló, alapos szakirodalom nemcsak a jogtörténészek számára, ugyanakkor érdekes és izgalmas olvasmány a minisztérium története, a dualizmus korának jogalkotói tevékenysége, és a két világháború közötti időszak jogtörténeti vonatkozásai iránt érdeklődő olvasók számára is.

A kötet ajánlásában Trócsányi László is összefoglalta a mú legfontosabb erényeit: „Antal Tamás és Révész Béla azonban nem történetet, hanem intézménytörténetet irt. A nagy történelmi cezúrákat kevéssé hangsúlyozzák. (...). A korszakhatárok gyakran csak utólag látszanak. Másrészt az állami intézmények müködése, küldetése általában a‡, hogy a folytonosságot képviseljéke és szuervezeti müködésükben tompitsák a változásoke élét."

A kötet alapját a levéltári források jelentik, amelyek jelentős része - ahogyan arra a szerző a bevezetésben utalt - az 1956-os tűzvész során megsemmisült. Az Igazságügyminisztérium múködésérôl tanúskodó dokumentumok egyáltalán nem állnak rendelkezésre, így ennek feltárása csak közvetett források alapján (volt) lehetséges. Ezzel magyarázható az is, hogy a minisztériumról részletes monográfia nem készült. A kötetet a szerző az igazságüggyel kapcsolatos kutatások kiindulópontjaként, mintsem a kiteljesedéseként jellemezi.

A könyv négy nagy fejezetből épül fel. Az első rész a minisztérium szervezéséről és szervezetéről szól. Nyomon követhetjük a minisztérium létrejöttének egyes lépéseit, a magyar igazságügy alapjainak a lerakását Deák Ferenc vezetése által. Az 1848-ban született igazságügyi tárgyú jogszabályok közül kiemelkedő fontosságú volt az esküdtbíráskodásról szóló rendelet. Az Országos Honvédelmi Bizottmánynak nem lehetett a feladata az igazságügy átfogó szabályozásának a megalkotása, mégis kiemelhető a hadiállapotban történő visszaélések szabályozást rendező rögtönbíráskodásról szóló vésztörvény. A neoabszolutizmust követően a kiegyezési tárgyalások alapján állt helyre az 1848. évi alapokon álló minisztérium, és születtek meg később a törvénykezésre és a bírák jogállására vonatkozó jogszabályok. Részletes képet kaphatunk a minisztérium belső szervezetéről, az egyes ügyosztályok feladatairól. A minisztérium belső szervezetének történetét vizsgálva három korszakot különböztetett meg a szerző: a 19. század utolsó harmadát, majd ezt követôen a forradalmak idejét, végül pedig az (ebben a tekintetben is) viszonylag sok változást hozó Horthy-korszakot. Érdekes és olvasmányos alkotóeleme a kötetnek a jogtudós (Horvát Boldiz̧ár, Pauler Tivadar, Sžilágyi Dezsoó, Erdély Sándor, Plósz Sándor, Balogh Jenö, Vladár

\footnotetext{
1 ANTAL Tamás: Az Igazságügyi Minisztérium története (1867-1944). Fejezetek a polgári kor évtizedéből. Budapest 2018, 327 p. ISBN: 9786155710513
} 
Gábor) és a politikus (Tomcsányi Vilmos Pál, Pestby Pál, Zsitvay Tibor, Lázár Andor, Radocsay Lászlô) igazságügyminiszterek méltatásokkal, idézetekkel ellátott, képekkel illusztrált életútjait részletesen bemutató rész. Az első fejezet zárása az igazságügyi igazgatás személyzetét mutatja be. Az igazságügyi szervezet egyes fizetési osztályai mellett teljes képet kaphatunk a vonatkozó jogszabályokról is.

A kötet második, viszonylag rövidebb részében a jogalkotási tevékenység, a korszak kodifikációinak a bemutatására vállalkozott a szerző. Ez a rész igazi jogtörténeti csemege, amelynek kezdetén az igazságügy szervezetét érintő jogszabályok összefoglalására került sor. A polgári korszakon belül a jogszabályok tekintetében két reform-periódust különböztet meg Antal Tamás. Az első reform-periódus az 1867 és 1889 közötti időszakot jelöli, ekkor született meg, majd a „magyar történeti alkotmány egyik föpillérévé vált” a bírói hatalomról és a szolgálati jogviszonyról szóló 1869. évi IV. törvénycikk. A második periódus 1889-ben, Szilágyi Dęső kinevezésével kezdődött, és számos fontos és meghatározó jogszabály megalkotására került ekkor sor (például az ítélőtáblák decentralizációja, a budapesti törvényszék önállósítása, az esküdtszék szabályozása). A büntetőjogi kodifikációk körében elsőként az anyagi jog, a Csemegi-kódex létrejöttének menetét és az azt kiegészítő törvényeket, valamint azokat a jogszabályokat, amelyek önállóan tartalmaztak büntetőjogi tényállásokat (például a tenger alatti kommunikációs kábelek megrongálása, az erdő-és mezőgazdasági kihágások köre, az árdrágító visszaélések, a szerzői jogi bitorlás, a vagyont és az erkölcsiséget sértő, ismét botbüntetéssel sújtható bűncselekmények, a zsidókkal való házasságkötés tilalmának a megszegése) ismerhetjük meg. Az eljárásjoggal foglalkozó részben olvashatunk a sajtóesküdtszéki eljárásra vonatkozó tervezetekről és jogszabályokról, valamint a Hortbykorszakban született változásokról is. A két világháború közötti időszakban felmerült problémák kivételes hatalom, a trianoni békeszerződés végrehajtása, a gazdasági stabilizáció, a növekvő szélsőségek - rendezése újabb kihívások elé állította a jogalkotót. A polgári jogi kodifikációhoz vezető út - szemben a büntetőjoggal - rögösnek bizonyult. Az 1848-ban elindult kodifikációs munka eredményeképpen számos résztörvény (a házassági jog, a végrendelkezés alaki kellékei, a földbirtok megosztása, a csődjogi intézmények korszerú szabályozása) született, és 1914-tôl ezen a terén is egyre jelentősebb szerep jutott a rendeleti jogalkotásnak. Antal Tamás átfogó képet ad a vizsgált korszak jogalkotásáról, és ahogy arra ajánlásában Trócsányi László utalt: „Egyes törvények vagy hatályos joggá nem vált törvényjavaslatok - megoldásait a 2010-2018-as két parlamenti ciklus jogalkotása is figyelembe vette".

A harmadik rész a minisztérium közigazgatási tevékenységét mutatja be. Nyomon követhetjük, hogy milyen lépésekben történtek az igazságügyi beruházások a fővárosban és vidéken. Érdekes kulisszatitkokat is találunk a törvénykezési szervezet személyi ügyeit tárgyaló részben. 1920-ban született meg a törvénykezési szervezet tagjai számára az önálló státuszt és illetményrendszert szabályozó jogszabály. Ezt követően indultak meg a bérrendezésről szóló tárgyalások. Béremelésre ugyan nem vezettek az egyeztetések, azonban egyéb juttatásban (családos igazságügyi alkalmazottak pénzjutalma, családi pótlék) részesültek az igazságügyben dolgozók. A követelések azonban ezzel nem értek véget, az 1920-as években számos módosítást hajtottak végre a bírákra és az ügyészekre vonatkozóan (pl. rangok szabályozása). Az 1930-as években a világgazdasági válság a minisztériumot is takarékosságra szorította. Az igazságügynek a szerepe a zsidóságot diszkrimináló jogszabályok végrehajtásában máig feltárására váró területe a 
jogtörténetnek. Antal Tamás fontos adalékokkal járul hozzá ehhez a feltáráshoz, amikor a negyedik zsidótörvényhez (1942. XV. törvénycikk) kapcsolódó dokumentumok alapján tárta fel zsidóktól elvett mezőgazdasági ingatlanok birtokszerzőivel foglalkozó tárgyalóbizottságokat, amelyeknek elnökei bírák vagy igazságügyi tisztviselők lehettek. Külön fejezetet szentelt a szerző a tanácsköztársaság alatti cselekmények, az anarchizmus elleni igazságügyi és külügyi együttmúködés, valamint a második világháborúban bekövetkezett változások bemutatásának (így például az antiszemitizmus jogi és gazdasági kivetülésének) is.

A negyedik részben a minisztérium 1914 és 1923 közötti időszakának bizalmas irataiból olvashatunk. Az első világháború kezdetétől követhetjük végig azokat a jogszabályokat, amelyek a hadiállapotra vonatkoztak. Ezek jelentős része alacsonyabb szintú jogszabály, rendelet, körrendelet, bizalmas utasítás volt (ellenség betörése esetén követendő intézkedések; büntetô hatóságok tevékenysége közvetlen veszély esetére; az igazságügyi hatóság rendes múködésének a beszüntetésére vonatkozó előírások; személyzeti hiányokra vonatkozó utasítás). Külön fejezetet szentel a szerző az utolsó magyar király jogállásának a bemutatására, hiszen az Igazságügyminisztériumban is többször foglalkoztak $I V$. Károly joghelyzetével és a probléma lehetséges megoldásaival (gyámkormányzói tisztség, nádori méltóság). A zárórész az Igazságügyminisztériumnak az egyéb minisztériumokkal (Hadügyminisztérium, Külügyminisztérium) való együttmúködését vázolja fel a békekötés időszakában.

A kötet második felét a levéltári munka során feltárt levéltári dokumentumok alkotják, amelyek tizenkilenc különböző iratanyagot foglalnak magukba, így például elolvashatjuk Bánffy Dęső miniszterelnök észrevételeit az esküdték szervezéséről szóló törvény végrehajtási rendelettervezetével összefüggésben 1898-ból, vagy Gr. Teleki Pál miniszterelnök átiratait a Nemzetpolitikai Szolgálat múködésével kapcsolatban 1940-ből és 1941-ből, vagy az izraeliták földingatlanairól szóló kormányrendelet végrehajtásához kapcsolódó igazságügyi dokumentumokat is megismerhetjük.

Bár Antal Tamás az igazságüggyel kapcsolatos kutatások kiindulópontjaként jellemzi a könyvét (és valóban számos irányba lehet(ne) belőle továbblépni), azonban az olvasó így is teljes, részlet- és adatgazdag képet kap olvasmányos, élvezetes stílusban, igényes illusztrációkkal az igazságügyminisztérium 1867 és 1944 közötti történetéről. Mindezek alapján jó szívvel ajánlom Antal Tamás könyvét mindenkinek a figyelmébe. 